\title{
D through Z: Politics in the Making
}

PATRICK BLENKARN

This text is inseparable from the way in which I am striving to create art as a theatremaker. Its words are a part of each production I participate in, for they attempt to set political standards for my work. By "political" I mean to denote the continually in flux process of recognition and individuation of a body within a collective. Therefore, as I understand the concept, the political is not definitively State determined. Political relations, rather, make up a multiplicity of territories - the State is but one of them.

To engage with theatre's political possibilities, its possibilities of engaging with and contributing to this process of recognition, I argue that we must go beyond a consideration of human bodies interacting or communicating with simply other human bodies. We must investigate the ways in which we humans collaborate with material 'bodies' of all kinds, and think about the different roles that these different bodies play in the process of theatre production-I use 'production' here to straddle the categories of rehearsal and presentation. A consideration of materiality in theatre production, I believe, reveals a certain structureone subtending much of our practice - that encourages the exclusion of certain materials and their meanings. I ask: is resistance to such exclusionary methods possible in this art? Can we expand the territory of political theatre to include the production as a whole, to include those things we so often deem superfluous? To explore these questions, I draw upon certain concepts of the French philosopher Gilles Deleuze, such as assemblage and difference, and on theatre discourse. I also draw on my own experiences of learning the theatrical ropes in Canada and the United States.

The theatre I have learned while playing in these ropes finds no better articulation than in Deleuze and Félix Guattari's concept of the assemblage. The authors write: "We will call an assemblage every constellation of singularities and traits deducted from the flowselected, organized, stratified - in such a way as to converge [. . . artificially and naturally" (406). Like the celestial constellations we see from Earth, composed of great gaseous stars flying at high speeds, the assemblage Deleuze and Guattari describe is not fixed, nor are its components. Bringing this concept into theatrical discourse (something many theatre thinkers did before I ever did) enables one to conceive of the way that we produce theatre to be a process of assembling various kinds of malleable material bodies. In the making of theatre, different elements collide and combine over a period of time, changing themselves and each other. At no point does this assembling really stop. Even in presentation, new materials join the party, and others connect in slightly different ways.

And yet, despite the flow of assembling, its instability and spontaneity, we theatrophiles, for the most part, and without a pause for thought, organize our production materials into two camps: humans and non-humans.

There are many different kinds of human materials, whose significance and differences are greatly respected. On stage we find the human performer. To these people, who are often 
courted based on their history and experiences, we give great respect both during the rehearsal process, and great focus during the 'show'. They dance, they sing, they speak, they move, they emote. We talk to these humans a lot, are patient with them, protect them.

Behind the stage, a myriad of humans are directing, designing, box office running, stagemanaging, and doing what crews do. We give to the different humans in this catchall category various kinds of great authority and trust. Some of them disappear at the moment of presentation; others are not incorporated until this very point. Though often ghosts on opening night, they typically decide the big decisions and make up the majority of human material in the production, at least until the spectating human arrives.

Like the performer, these last humans are similarly courted, endlessly listened to, even asked to share their own opinions. Whether we take their money or not, the spectator's belongings and rights are highly respected. Of note, these humans are so well respected that we even show pre-emptive concern for their health history, warning them of strobe lights and other deadly bodies.

Non-human materials can, and for the most part do, have very different functions within production than human materials. Many more kinds of non-human material exist than human material and they are treated with significantly less respect than the latter. My description of these materials follows the ways in which humans speak of them throughout the production process, how they are often used and viewed by humans. (The common link of human organization and interpretation should not be overlooked.)

Some non-human materials do take on roles within a production that seem to elevate them above their fellow brute stuff. For example, puppets or the glass pieces in The Glass Menagerie or other Chekhovian guns that sit upon the stage imbued with great significance by scenic design, text, or action. These materials are usually chosen and presented with great care, carefully painted or maintained, even studied.

However, such non-human materials of great significance are by far the least populous on this side of the organizational divide. For the most part, material of the non-human persuasion finds itself in the literal or figurative trash, deemed unnecessary, for example, by most theatrical discourse. Twentieth-century critic Eric Bentley created a now commonplace model of essential theatrical components in his book, The Life of the Drama: "A imitates B while C looks on" (150). The clarity of his model comes at the cost of stripping away the 'stuff' (perhaps D through Z) and all that stuff's potential. Bentley's model and others like it continue to find a place in popular conceptions of theatre. Playwright David Mamet, for example, takes up a version of the ABCs when he writes in his book, Theatre, "One does not require equipment but the insight and bravery to perceive that one does not require equipment" (80). In short, in reference to most materials, we human theatremakers frequently say, "You don't need that" - the subtext of this line being that the material could add no meaning to the production.

For those non-human materials we can't simply sever off, we treat them as merely empty of significance altogether. I speak here, for example, of costumes or 'spaces'. Peter Brook, perhaps following in Bentley's model-making footsteps, presents his own version of the ABCs of theatre at the outset of The Empty Space. He writes, "I can take any empty space and call it a bare stage. A man $[s i c]^{\mathrm{I}}$ walks across this empty space whilst someone else is watching him, and this is all that is needed for an act of theatre to be engaged" (9). I don't think Brook's 
intention was to inspire or contribute to the ideology I try here to point out. Much of his work demonstrates quite the opposite. Nonetheless, his text is a pillar of theatre education, and a certain 'empty space' mentality forms much of the foundation of our small to mediumsize festivals and independent theatre. Many festivals, like the Fringe, discourage artists from letting the aesthetic of the performance space act as an integral, let alone, decided upon, element of the production. In these increasingly popular forms of presentation, the production has 15 minutes to set up and tear down on the ever-black stage. ${ }^{2}$

Lastly, at a certain level of professional production, a division of labour within the creation process allows for materials to be deferred by some or deemed unnecessary for some, but not all. The material becomes 'not my problem'. For example, the Canadian Actors' Equity Association's Canadian Theatre Agreement (ironically, a highly respected non-human material itself and the star of many productions) demands an actor to "respect the physical property of the production" (“Canadian Theatre Agreement” 32). Speaking from experience, this respect, in practice, often translates to one not engaging with the material outside of running scenes. In short, an odd unspoken policy demands certain people to engage with certain materials in certain ways at certain times, but to ignore them otherwise.

I present these categories in some length to approach the argument that, though no material part of the theatre assemblage figures as any less part of the whole than any other, an organization persists. This organization depends upon conceptions of what can and cannot contribute meaning to a production. The cases of non-signifying or 'not my problem' materials demonstrate a belief that certain materials may have the potential for more meaning than others. The point, therefore, is that in the seemingly benign gestures of creating 'significant' objects (if that), and deeming others non-signifying or 'not my problem', we see two kinds of policing at work. First, it seems that we, as humans, are of a different material order, one that transcends brute stuff and is inherently full of meaning and potential in the eyes of each other. Second, it seems that we, as humans, actually control the signification of materials. We decide that the gun is significant, but the bottle of wine, perhaps with an anachronistic label on it, is not. We have convinced ourselves (or let other forces and agents convince us) that we humans are the first and can do the second, neither of which is actually the case.

To be clear, these self-aggrandizing gestures are not the case on the grounds that, by virtue of human participation in the event, all material within the theatre assemblage is subject to the same relationship between matter and meaning. In his book, Postdramatic Theatre, theorist Hans-Thies Lehmann, a notable adopter of Deleuze's concept of the assemblage, explains this predicament well. He argues that every theatre event, by virtue of its engagement with language's system of signs, is composed of doubles. He writes, "Theatre is at the same time material process - walking, standing, sitting, speaking, coughing, stumbling, singing - and 'sign for' walking, standing, sitting, etc. Theatre takes place as practice that is at once signifying and entirely real" (IO2). Though Lehmann remains focused in part on human material, using the human body as his example, I do not believe his structure to be exclusive to humans. For as long as a material, of any kind, has been incorporated into the process of production, it participates in the same double structure he articulates - which in action might be a tripling, or quadrupling of the sign. For bow is the actor walking or standing? What other signs are colliding with and coding the material? The white room is perhaps a white room, and an asylum, and heaven, and purgatory - the signifying chains go on. 
In short, any material always remains as much the subject of aesthetic interpretation as any other material, particularly within theatrical production in which the polyvalence of meaning seems a, if not the, convention of the art. Why do we say to actors that they must assume that someone is watching them all the time, and not recognize that someone, instead, may be watching the set or the lights or the costumes all the time? Each nonhuman material has the same interpretative possibilities when 'performing' as the performer does: it has a history of, or trace of what it has been in the past, what is it now on stage, and what it could be.

Therefore, the acts of policing matter and meaning participate in a familiar structure of political exclusion. Though indeed isolated acts, these policings, at the level of form, also belong to a series of exclusory acts: a tradition that recognizes the paid over the unpaid, the necessary over the superfluous, the active over the passive, the speaking over the silent, the mobile over the paralyzed, and so on-a tradition that recognizes those materials participating in the A position of these binaries as more meaningful, as richer in life, expression, and signification. In these terms, I consider the policing acts in question, so commonplace to our theatre work, to be citations, or repetitions of exclusions of people, of animals, of things, of environments in a more local, artistic, and pragmatic context.

Simply put, I am suggesting that these exclusory gestures guide the production of much of our art. I have already briefly mentioned Fringe festivals and professional unionized production as situations in which the structures we work within encourage a lack of decision-making. With the former, and its familiars, we have situations that brew a kind of vulgar minimalism of unquestioning storytellers, often alone in 'space'. With the latter, and its familiars, we have a sterilized and stratified ecology: theatre as painting by numbers and drowning by numbers.

Some artists - often those with their own social and economic privileges, I admit-have resisted and wrestled with these guiding hands of exclusion. New York avant-gardist Richard Foreman, for example, employs the concept of equality to separate his method from the norm. He refers to theatrical elements as akin to each note used within I2-tone music ("Idiot Savant"). And Foreman is not the only one to aim for equality. However, pragmatically speaking, equality doesn't help me work: actors are not chairs, nor chairs actors. But the thought is in the right direction. In Difference and Repetition, Deleuze tells us that equality and resemblances are often confused with difference (3). Introducing the concept of difference to our methods of work allows us I) to think each material as 'equally' part of (that is, no less part of, no less or more 'different' within) the assemblage, and 2) to recognize that each material presents a unique problem (of presence, of meaning) to the greater assemblage. This unique problem demands a unique, which is not to imply any sense of proper, solution. The problem that a spectator presents is very different from that which the performer presents, both of which are different from the space or costumes.

To the reader of these words, I ask: how do we change the statements, "You don't need that," or "that's unnecessary," into questions, such as, "What would D through Z contribute?" How can we have done with judgment and begin a theatre practice of questioning? For, in my experience, each problem provokes questions: How does it connect? How does it work? What does it bring to the assemblage? What does it change? What do we do about it? Each problem posed sparks at least some thought, some question of possibilities. Searching for a 
solution to the problem, really questioning the material's relation to others, considering its possibilities and significance, demonstrates one's ability to respond to the material relations that make up the production, and to be responsible for the territory within which one exists and creates.

To introduce difference into material relationships, to recognize that there is no single (material) difference between all humans in the production and all objects, enables one to conceive the responsibilities that our material relationships imply. In this assemblage, I believe being political means taking responsibility for each and every material, and thus going against the grain of traditional labour division limitations - 'Every problem is my problem', whoever 'I' am. As actor I am responsible for words, props, spectators, and lights. As writer I am responsible for how the words will sound by any who speak them, what situations the words will try to put the actor in (physically or mentally), and what the words might make the spectator feel or think. As spectator I am responsible for my conclusions, for my physical presence and relation with my environment, and so on.

But this idea of responsible practice soon reaches an impasse. As Deleuze and Guattari's concept of the ever-assembling assemblage suggests, theatre, despite always being 'full', is quite insatiable. Theatre eats everything that comes its way: materials (human or not), other art forms (dance, cinema, music, performance art, painting, sculpture, etc.), technologies (projection, iPods, etc.), ideas (will we ever run out?). By virtue of this potential, this flux, this being both "completed and unlimited," I argue that we will always come up short in every production process; something will always escape us, always end up excluded or deemed unnecessary, waste (Difference and Repetition 57).

The challenge that such a formulation of difference puts forward, particularly as read through the problem-solution language I have learned from Deleuze, is to keep going and not find a crutch in deferring the responsibility that comes with engaging with the world to some other figure, whether actual or imaginary. Too often in my experience have the local politics of the production itself been deferred, or ignored, in the attempt to create a better, further reaching political presentation.

On the note of territory, I ask and conclude: what place can theatre production have as a political agent? Theatre is not in high demand, neither as political event nor as entertainment. The art is increasingly marginalized, while other forms of storytelling are thriving. In the past, we have understood political theatre by way of its message (Bertolt Brecht) and by way of its re-writing the relationships between some of the (human) elements within (Augusto Boal's 'spectactor'). By emphasizing the necessity to politicize production, I am attempting to expand upon gestures like these, to incorporate them, at the same time as address a formal politics with which they do not fully engage. That is to say, I wish to expand the territory of the political to include working relationships between materials of every kind. By at least resisting structures of exclusion, theatre production might be an event in which we participate in order to cultivate new ways of thinking in and of being in this world: that is, not some place we simply go to receive or to put forward political messages, but some place in which we all (on, behind, or in front of the 'stage') actually live politically with each other, as recognized singularities that directly recognize other singularities. To steal more words from Deleuze, here from his essay, "To Have Done With Judgment": "It is not a question of judging other existing beings, but of sensing whether they agree or disagree with us, that is, whether they 
bring forces to us, or whether they return us [. . . ] to the rigors of organization" (135).

Even though we can't all tell the stories of the marked and excluded, I believe we can all make art, even if at the level of form, that does not encourage exclusion. Even if an absolutely democratic theatre will always be impossible, the material-based practice of making theatre must not be exempt from the politics that that practice strives to bring about. The form of one's practice is political. Aesthetic decisions are political decisions.

\section{Notes}

I With embarrassment I note here Brook's gendered example and also warn my reader that the rest of this essay's sources are perhaps not much better. In part, I attribute the unbalance of my predominately white male sources and examples to the aim of my critique: to call on specifically (but not limited to) those theatremakers with social and economic privileges to consider the political roots and implications of their production methods - to enter the debate.

2 One form of resistance from within the Fringe circuit to these limitations is the relatively recent Bring Your Own Venue (BYOV) option. By choosing this option, artists have the ability (though do not necessarily take advantage of the opportunity) to engage with their space in a more detailed way. In short, BYOVs go either way. The best venue for you might, after all, be so far away from the local cluster of Fringe spaces that spectators don't come.

\section{Works Cited}

Bentley, Eric. The Life of the Drama. New York: Atheneum, 1975. Print.

Brook, Peter. The Empty Space. New York: Touchstone, 1968. Print.

“Canadian Theatre Agreement 20I2-2015." Canadian Actors' Equity Association. I2 June 2012. Web. IO Apr 2014.

Deleuze, Gilles. Difference and Repetition. Trans. Paul Patton. New York: Columbia UP, 1994. Print.

—. "To Have Done With Judgment." Essays Critical and Clinical. Trans. Michael A. Greco and Daniel

W. Smith. Minneapolis: U of Minnesota P, 2009. Print.

Deleuze, Gilles and Félix Guattari. A Thousand Plateaus. Trans. Brian Massumi. Minneapolis: U of Minnesota P, 1987. Print.

Foreman, Richard. "Idiot Savant Interviews" YouTube.com. The Public Theater, 9 Oct 2009. Web. 27 Feb 20 Iо.

Lehmann, Hans-Thies. Postdramatic Theatre. Trans. Karen Jürs-Munby. New York: Routledge, 2006. Print.

Mamet, David. Theatre. New York: Faber and Faber, Inc. 20Io. Print. 